\section{OPTIMIZATION OF REFLUX EXTRACTION FOR CAESALPINIA SAPPAN LINN. WOOD BY USING RESPONSE SURFACE METHODOLOGY}

Mohd Azahar Mohd Ariffa,c*, Muhammad Syafiq Abd Jalila, Noor 'Aina Abdul Razak', Jefri Jaapard

aFaculty of Chemical Engineering, Universiti Teknologi MARA, Cawangan Pulau Pinang, 13500 Permatang Pauh, Pulau Pinang, MALAYSIA

bFaculty of Computer Science and Mathematics, Universiti Teknologi MARA, Cawangan Pulau Pinang, 13500 Permatang Pauh, Pulau Pinang, MALAYSIA

cMolecular System Design, Process \& Optimization Research Group (MODEPRO), Universiti Teknologi MARA, Cawangan Pulau Pinang, 13500 Permatang Pauh, Pulau Pinang, MALAYSIA

dFaculty of Chemical Engineering, Universiti Teknologi MARA, 40450 Shah Alam, Selangor, MALAYSIA
Article history

Received

23 January 2020

Received in revised form

26 November 2020

Accepted

3 December 2020

Published online

17 December 2020

*Corresponding author azahar.ariff@uitm.edu.my

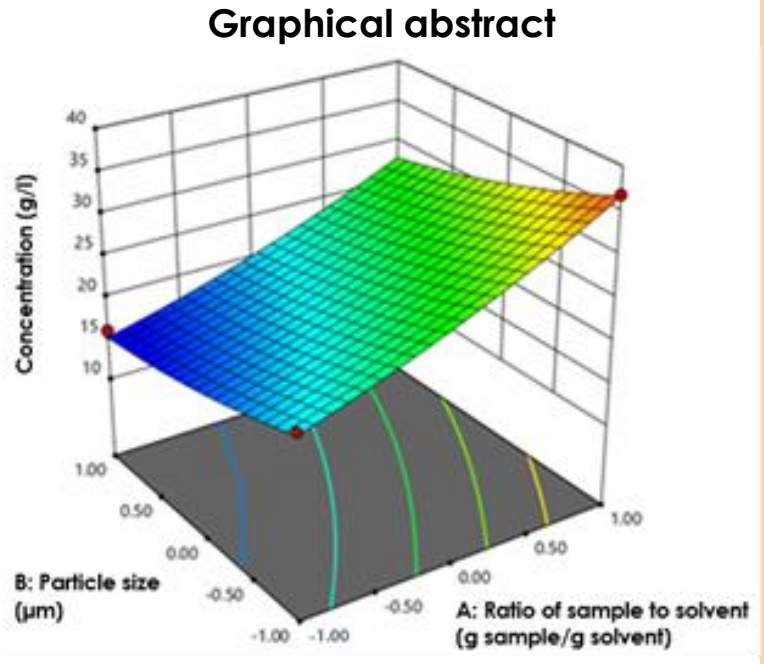

\begin{abstract}
Caesalpinia sappan linn. (CSL) is a plant which is also known as Sepang tree contains various medicinal values such as to treat diarrhea, skin rashes, syphilis, jaundice, drinking water for blood purifying, diabetes, and to improve skin complexion. The aim of this study is to obtain the most optimum condition in terms of the ratio of sample to solvent, particle size, and extraction time to get the highest amount of concentration of the CSL extract. In this study, the ranges of each parameters used were: ratio sample to solvent: 1.0:20, 1.5:20, 2.0:20, 2.5:20, 3.0:20, particle size: $1 \mathrm{~mm}$, 500 um, 250 um, 125 um, 63 um, and extraction time: 1 hr, 2 hr, 3 hr, 4 hr, 5 hr. The concentration was analyzed using a UV-vis spectrophotometer. The optimum conditions were obtained by response surface methodology. From the design, 20 samples were run throughout this experiment. The optimized value from the RSM were 2.0:20 for ratio sample to solvent, $125 \mu \mathrm{m}$ of particle size and 2.48 hours with the concentration of $37.1184 \mathrm{ppm}$. The accuracy of the predictive mode was validated with 2 repeated runs and the mean percentage error was less than $3 \%$. This confirmed the model's capability for optimizing the conditions for the reflux extraction of CSL's wood.
\end{abstract}

Keywords: Caesalpinia Sappan Linn., Responce Surface Methodology, Reflux extraction, UV-vis spectrophotometer, Optimization 


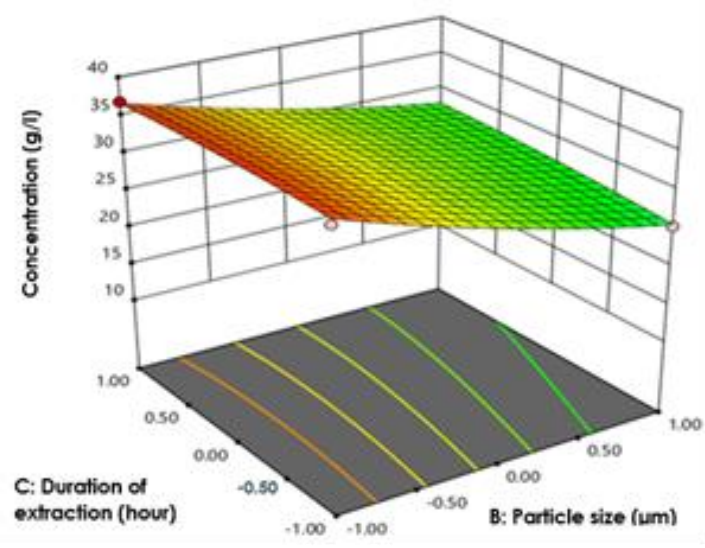

\begin{abstract}
Abstrak
Caesalpinia sappan linn. (CSL) adalah tumbuhan yang juga dikenali sebagai pokok Sepang yang mengandungi pelbagai nilai perubatan seperti merawat cirit-birit, ruam kulit, sifilis, jaundis, air minuman untuk pembersihan darah, diabetes, dan pemulihan permukaan kulit. Tujuan kajian ini adalah untuk mendapatkan parameter yang paling optimum dari segi nisbah sampel kepada pelarut, saiz serbuk, dan masa pengekstrakan untuk mendapatkan jumlah tertinggi kepekatan ekstrak CSL. Dalam kajian ini, julat bagi setiap parameter yang digunakan adalah: nisbah sampel kepada pelarut: 1.0: 20, 1.5: 20, 2.0: 20, 2.5: 20 , 3.0: 20, saiz serbuk: $1 \mathrm{~mm}, 500 \mu \mathrm{m}, 250 \mu \mathrm{m}, 125 \mu \mathrm{m}, 63 \mu \mathrm{m}$, dan masa pengekstrakan: 1 jam, 2 jam, 3 jam, 4 jam, 5 jam. Kepekatan dianalisa dengan menggunakan spektrofotometer UV-vis. Untuk mendapatkan keadaan optimum kepekatan, metodologi Response Surface Methodology (RSM) telah digunakan. Daripada reka bentuk RSM, 20 sampel telah dijalankan sepanjang percubaan ini. Nilai yang dioptimumkan dari RSM adalah 2.0:20 untuk nisbah sampel kepada pelarut, $125 \mu \mathrm{m}$ untuk saiz serbuk dan masa 2.48 jam dengan kepekatan $37.1184 \mathrm{ppm}$. Ketepatan ramalan model telah dibuat pengesahan dengan menjalankan 2 kajian ulangan dan purata ralat peratusan adalah kurang daripada $3 \%$. Ini mengesahkan keupayaan model untuk mengoptimumkan parameter bagi pengekstrakan refluks kayu CSL.
\end{abstract}

Kata Kunci: Caesalpinia Sappan Linn., Response Surface Methodology, Pengekstrakan Reflux, Spektrofotometer UV-vis, Pengoptimuman

(C) 2021 Penerbit UTM Press. All rights reserved

\subsection{INTRODUCTION}

Nowadays, natural resources like plant stem and leaves have become favorable to cure various kinds of diseases and made into herbal medicine to improve health quality. This can be ascribed to the fact that the presently synthetic medicines are either high cost or tend to have side effects [1]. The Caesalpinia sappan Linn. (CSL) is one of the natural resources examples that has been used traditionally as it has various medicinal properties [1]. The CSL is a spreading tree up to 10 meters in height, found wild, and cultivated throughout the Asian tropics like South India, Thailand, Sri Lanka, and Malaysia [1], [2]. Almost every part of CSL plant has medicinal purposes. The characteristics of the wood are hard, straight-grained with an even texture, and redorange color [1]. The heartwood of the CSL is used to treat diarrhea, skin rashes, syphilis, jaundice, drinking water for blood purifying, diabetes, as well as to improve skin complexion [1]. The major active component found in the CSL is brazilin, which is well known as the natural red pleochroism dye. The brazilin has been studied to possess numerous biological activities like antibacterial, antiphotoaging, hypoglycemic, vasorelaxant, anti-acne, anti-inflammatory, antioxidant, and nuclease activity [1], [2], [3].

There are various methods of fluid extraction from the plant that produces an excellent quality product and can be categorized as the conventional extraction method and non-conventional extraction method. The examples of the conventional extraction methods are hydro-distillation, maceration, soxhlet extraction, reflux extraction, and percolation extraction. Non-conventional extraction methods like Microwave-Assisted extraction (MAE) and Supercritical Fluid extraction are also known as modern extraction methods. Both types carry the same purpose which is to extract the active component from any part of the plant that can be used as drugs, food, and herbal medicine. The conventional extraction method is economical friendly compared to the unconventional extraction method as it required simpler equipment for the extraction process. According to research, almost $90 \%$ of the small and medium scale production industries use conventional method in their production process [4], [5], [6].

The reflux extraction is a conventional method that has been favorable in industries because it is economical friendly, not complex, and easy to handle [4], [7], [8], [9]. It operates at the boiling point temperature of the solvent with reiteration of solvent evaporation that condense back to the liquid state with the aids of condenser at selected time without deprivation of solvent. The solvent that contains the extract will evaporate from the three-neck round bottom flask and pile up inside the reflux condenser column and then condense back to the liquid phase by the cooling water. In order to accelerate the organic reaction, the solvent with the plant parts is boiled to extract the active component. The extracted liquid will be separated using vacuum pump. The duration of extraction [7], [10] and type of solvent [11], [12], [13] are the parameters frequently 
interrogated for reflux extraction. Response surface methodology (RSM) is a statistical approach that helps to appraise the effect of numerous factors like particle size, ratio of solid to solvent, pressure, and temperature to determine the best state for a designated response while reducing the iteration of experiment required [14]. In simple words, it is necessary to use RSM because it is an effective method as it requires shorter time and use less raw materials to determine the best state in the process especially in the massive-scale process [15]. It is better to use Central Composite Design (CCD) compared to using the Box-Behnken design (BBD) for these three parameters because the CCD method requires lesser experimental runs and at the same time gives a a better result compared to BBD [14]. In this research, the best condition can be defined as the highest percentage yield of the active compound in the CSL wood. Design Expert 11 software was used to form a graph that illustrates the best conditions of the CSL wood extraction method.

The UV-vis Spectrophotometer (UV-vis) is a device used to analyze the chemical structure of matters, identify and measure the inorganic and organic compound [16], [17]. The benefits of using the UV-vis are excellent accuracy and sensitivity, wide application, and convenience to analyze the sample [16], [17]. The concentration amount of the redorange extract fluid of the CSL wood from the reflux extraction unit was analyzed by analyzing the UV-vis wavelength absorbance.

\subsection{METHODOLOGY}

Figure 1 illustrates the overall process flow for this research. Three parameters were selected which were the ratio of solid to solvent, the duration of extraction, and the particle size to determine the optimum condition of reflux extraction. Design expert 11 (DE 1 1) was used and the parameters were added into DE1 1 by using the CCD type [18].

Based on the DE11, 20 runs of designed experiments with 20 samples based on diverse parameters were generated. The CSL wood was purchased from the local herbal shop at Batu Pahat, Johor, Malaysia and the material was in the form of heartwood [2]. The wood was washed and rinsed using deionized water to remove the fine debris that might affect the experiment. The wood was scattered evenly into trays where they were continuously dried at $40^{\circ} \mathrm{C}$ for 2 days. The low temperature was set to ensure the wood manage to dry completely, and the active component would not degrade.

Next, the dried wood was ground into powder form to increase the total surface area. About $1 \mathrm{~kg}$ of the dried wood powder was sent to Kedah BioResources Corporation Sdn. Bhd. (KBioCorp), Kedah, Malaysia for extracting the CSL wood in the form of liquid and then transformed it into red-orange powdered form by using spray dryer. This extracted powder was then mixed with the deionized water and used as a standard for the readings (in ppm) of the UV-vis.

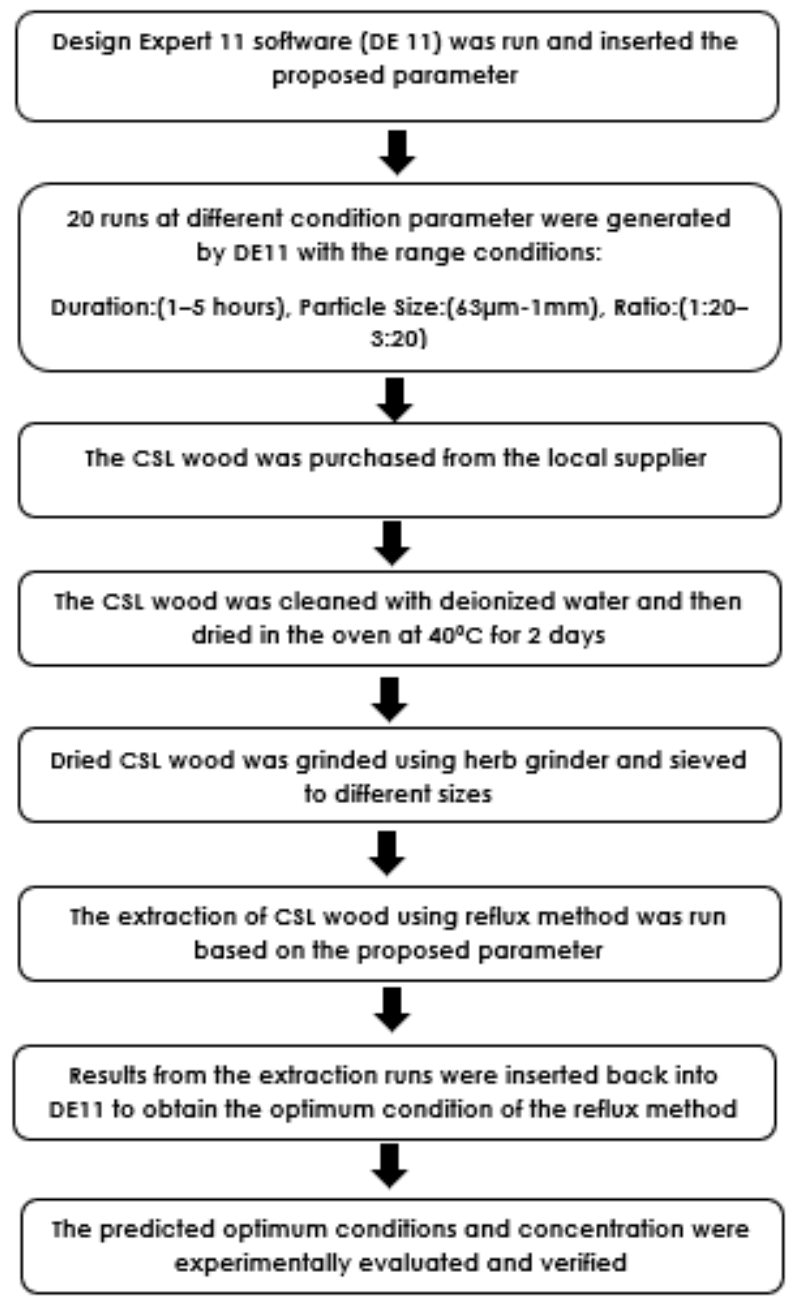

Figure 1 The process flow of the methodology of reflux extraction

The rest of the dried wood powdered form of the wood was then sieved into five selected sizes. Five varied sizes of wood were added with silica gel and kept in dry zipper bag to preserve it. The reflux extraction method was used to extract the samples. The reflux extraction involved combinations of boiling, heating, and refluxing at the selected time. The reflux procedure began by drenching the wood powder based on the size recommended by DE 11 in $200 \mathrm{ml}$ of solvent (deionized water) at a duration of time recommended by DE 11 . The solvent was then heated at the temperature of $100^{\circ} \mathrm{C}$ which was the boiling point of the solvent. The suction pump was used to filter the extracted sample.

The UV-vis spectrophotometer device was used to determine the extraction concentration. The results from the extraction runs were reinserted into the $D E$ 11 to obtain the optimum condition of the reflux 
method. The predicted optimum conditions interpreted by the DE 11 were experimentally evaluated and verified. The error between the predicted and experimental optimal condition of the reflux extraction was calculated and compared after analyzing the concentration using the UV-vis. The difference of the error was less than $10 \%$ to ensure the validity of the model.

Table 1 List of levels of the experimental parameters

\begin{tabular}{lllcccc}
\hline \multirow{2}{*}{ Factor } & \multicolumn{6}{l}{ Level of Range (coded) } \\
\cline { 2 - 6 } & $\mathbf{- 1 . 6 8 1 7 9}$ & $\mathbf{- 1}$ & $\mathbf{0}$ & $\mathbf{+ 1}$ & $\mathbf{+ 1 . 6 8 1 7 9}$ \\
\hline 1 & $\begin{array}{l}\text { Ratio of } \\
\text { sample to } \\
\text { solvent }\end{array}$ & $1.0: 20$ & $1.5: 20$ & $2.0: 20$ & $2.5: 20$ & $3.0: 20$ \\
2 & & & & & \\
2 & $\begin{array}{l}\text { Particle } \\
\text { size }\end{array}$ & $\begin{array}{c}0.063 \\
\mu \mathrm{m}\end{array}$ & $\begin{array}{c}0.125 \\
\mathrm{\mu m}\end{array}$ & $\begin{array}{c}0.250 \\
\mu \mathrm{m}\end{array}$ & $\begin{array}{c}0.500 \\
\mu \mathrm{m}\end{array}$ & $\begin{array}{c}1.000 \\
\mathrm{~mm}\end{array}$ \\
3 & $\begin{array}{l}\text { Duration } \\
\text { of } \\
\text { extraction }\end{array}$ & $1 \mathrm{hr}$ & $2 \mathrm{hrs}$ & $3 \mathrm{hrs}$ & $4 \mathrm{hrs}$ & $5 \mathrm{hrs}$ \\
\hline
\end{tabular}

\subsection{RESULTS AND DISCUSSION}

\subsection{RSM Regression Data Result}

Table 2 and Figure 2 show the regression data and line of predicted result versus actual result. The twenty dots represented twenty experiments that were conducted. The more dots fell on the regression line the more reliable the results would be. Based on Table 3, the value of regression $\left(R^{2}\right)$ after troubleshooting increased up to 0.979 . It proves that the data was reliable as the $R^{2}$ value closes to one [19]. The predicted $R^{2}$ of 0.9176 was in reasonable agreement with the adjusted $R^{2}$ of 0.960 when the difference is less than 0.2. The adequate precision function was to measure the signal to noise ratio. A ratio that is greater than four is desirable. As for this experiment, the value of 23.934 of adequate precision indicates an adequate signal.

Table 2 Coded Factor Level vs Extraction Concentration

\begin{tabular}{cccccc}
\hline Run & \multicolumn{2}{c}{$\begin{array}{c}\text { Coded } \\
\text { Factor Level }\end{array}$} & \multicolumn{3}{c}{$\begin{array}{c}\text { CSL Extraction Concentration } \\
\text { (ppm) }\end{array}$} \\
\cline { 2 - 6 } & $\mathbf{1}$ & $\mathbf{2}$ & $\mathbf{3}$ & $\begin{array}{c}\text { Final Actual } \\
\text { Value } \\
\text { (experiment) }\end{array}$ & $\begin{array}{l}\text { Predicted } \\
\text { Value } \\
\text { (RSM- } \\
\text { Quadratic) }\end{array}$ \\
\hline 1 & 1 & 1 & 1 & 27.063 & 27.770 \\
2 & 0 & 0 & 0 & 22.569 & 24.171 \\
3 & -1 & 1 & 1 & 16.046 & 14.981 \\
4 & 0 & 0 & 0 & 22.947 & 24.171 \\
5 & -1 & 1 & -1 & 17.294 & 17.667 \\
6 & 1 & -1 & 1 & 36.832 & 38.791 \\
7 & 0 & 1.6817 & 0 & 19.777 & 19.035 \\
\hline
\end{tabular}

\begin{tabular}{|c|c|c|c|c|c|}
\hline \multirow[t]{2}{*}{ Run } & \multicolumn{2}{|c|}{$\begin{array}{c}\text { Coded } \\
\text { Factor Level }\end{array}$} & \multicolumn{3}{|c|}{$\begin{array}{l}\text { CSL Extraction Concentration } \\
(\mathrm{ppm})\end{array}$} \\
\hline & 1 & 2 & 3 & $\begin{array}{c}\text { Final Actual } \\
\text { Value } \\
\text { (experiment) }\end{array}$ & $\begin{array}{l}\text { Predicted } \\
\text { Value } \\
\text { (RSM- } \\
\text { Quadratic) }\end{array}$ \\
\hline 8 & 1 & -1 & -1 & 36.160 & 36.688 \\
\hline 9 & 1 & 1 & -1 & 25.380 & 26.178 \\
\hline 10 & 0 & 0 & -1.6817 & 24.452 & 24.416 \\
\hline 11 & 1.6817 & 0 & 0 & 15.945 & 17.631 \\
\hline 12 & 0 & -1.6817 & 0 & 33.55 & 35.050 \\
\hline 13 & 1.6817 & 0 & 0 & 38.245 & 37.633 \\
\hline 14 & 0 & 0 & 0 & 25.407 & 24.171 \\
\hline 15 & -1 & -1 & -1 & 26.934 & 25.691 \\
\hline 16 & -1 & -1 & 1 & 21.643 & 23.515 \\
\hline 17 & 0 & 0 & 0 & 25.397 & 24.171 \\
\hline 18 & 0 & 0 & 0 & 23.774 & 24.171 \\
\hline 19 & 0 & 0 & 0 & 25.986 & 24.171 \\
\hline 20 & 0 & 0 & 1.6817 & 22.143 & 23.926 \\
\hline
\end{tabular}

\section{Design-Expert 요 Software \\ Trial Version}

concentration

Color points by value of concentration:

$15.945 \square 38.245$

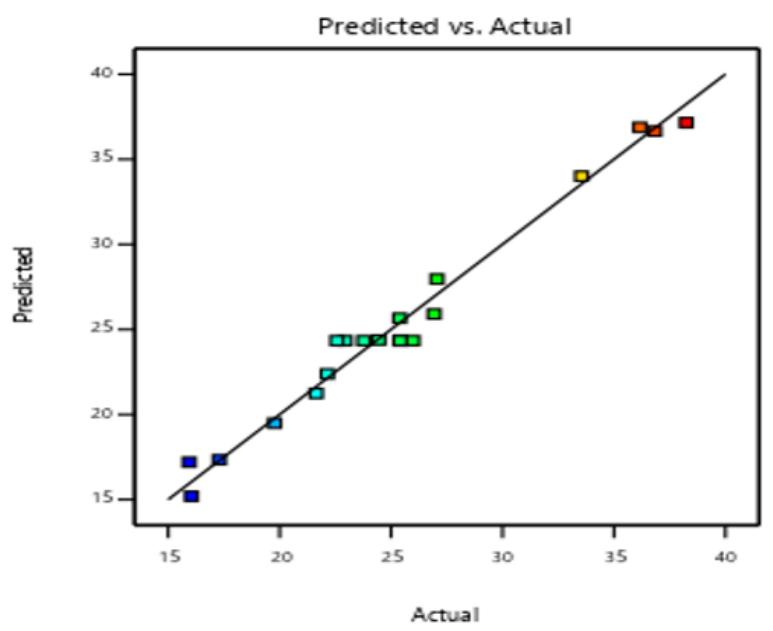

Figure $\mathbf{2}$ The predicted vs actual graph

Table 3 The Regression Score

\begin{tabular}{cccc}
\hline $\begin{array}{c}\text { STD. } \\
\text { DEV. }\end{array}$ & $\mathbf{1 . 3 0}$ & $\mathbf{R}^{\mathbf{2}}$ & $\mathbf{0 . 9 7 9 0}$ \\
\hline MEAN & 25.38 & ADJUSTED R & \\
C.V. \% & 5.11 & PREDICTED R & 0.9600 \\
& & ADEQ PRECISION & 0.9176 \\
& & & 23.9339 \\
\hline
\end{tabular}




\subsection{Development of Regression Model Equation}

The relationships between three parameters for this research were well fitted with the quadratic model.

Based on Table 4, the Model F-value of 51.68 implies that the model is significant. It is due to there is only a $0.01 \%$ chance that the F-value of this large could occur due to noise. Moreover, P-values of less than 0.05 indicates that the model term is significant [15], [19]. In this case, A, B, AC, A2, and $B^{2}$ are significant model terms. The model terms are considered not significant when the P-value is greater than 0.1 [15], [19]. Furthermore, the Lack of Fit F-value of 0.62 implies the lack of fit is not significant relative to the pure error. There is a $69.08 \%$ (P-value) chance that a lack of fit F-value. The higher the value of Lack of Fit F-value, the more likely that the model will effectively fit the data, and thus not-significant means good for the model. Besides, the quadratic models chosen were reliable and suitable for evaluating the predicting response (concentration) in the central composite design method when the value is more than 0.05. Furthermore, the prediction of concentrations were within the range of the designed parameters.

Table 4 Analysis of Variance (ANOVA) for regression model

\begin{tabular}{|c|c|c|c|c|c|c|}
\hline Source & $\begin{array}{l}\text { Sum of } \\
\text { Squares }\end{array}$ & df & $\begin{array}{l}\text { Mean } \\
\text { Square }\end{array}$ & $\begin{array}{c}\text { F- } \\
\text { value }\end{array}$ & $p$-value & \\
\hline Model & 783.02 & 9 & 87.00 & 51.68 & $<0.0001$ & significant \\
\hline $\begin{array}{l}\text { A-ratio } \\
\text { sample to } \\
\text { solvent }\end{array}$ & 480.80 & 1 & 480.80 & 285.57 & $<0.0001$ & \\
\hline $\begin{array}{l}\text { B-particle } \\
\text { size }\end{array}$ & 254.37 & 1 & 254.37 & 151.08 & $<0.0001$ & \\
\hline $\begin{array}{l}\text { C-duration } \\
\text { of } \\
\text { extraction }\end{array}$ & 4.78 & 1 & 4.78 & 2.84 & 0.1230 & \\
\hline$A B$ & 3.51 & 1 & 3.51 & 2.09 & 0.1791 & \\
\hline$A C$ & 9.87 & 1 & 9.87 & 5.86 & 0.0360 & \\
\hline$B C$ & 3.18 & 1 & 3.18 & 1.89 & 0.1993 & \\
\hline$A^{2}$ & 14.53 & 1 & 14.53 & 8.63 & 0.0148 & \\
\hline$B^{2}$ & 10.45 & 1 & 10.45 & 6.21 & 0.0319 & \\
\hline$C^{2}$ & 1.65 & 1 & 1.65 & 0.9808 & 0.3454 & \\
\hline Residual & 16.84 & 10 & 1.68 & & & \\
\hline Lack of Fit & 6.47 & 5 & 1.29 & 0.6248 & 0.6908 & $\begin{array}{l}\text { not } \\
\text { significant }\end{array}$ \\
\hline Pure Error & 10.36 & 5 & 2.07 & & & \\
\hline Cor Total & 799.85 & 19 & & & & \\
\hline$R^{2}=0.9790$ & & & & & & \\
\hline
\end{tabular}

\subsection{Process Parameters Studies}

The three dimensions of graphical illustration obtained from the DesignExpert software show the relationship between the responses and range of the parameters and type of interactions between tested parameters to get the optimum condition. All the three variables as shown in Figure 3 - 5, should demonstrate quadratic trends where the optimum point (red dot) should lay at the tip of the graph.

Figure 3 shows the three-dimensional response surface plot for the relationship between the reaction of sample to solvent and particle size. It was determined that when the ratio of sample to solvent was higher, maximum amount of concentration could be achieved [20], [21]. The concentration achieved was 38.245 ppm when the maximum ratio of sample to solvent was applied. However, it was vice versa for particle size. The concentration achieved was only 15.945 ppm when the largest particle size was applied. Thus, it was proven that the highest ratio of sample to solvent and the smallest particle size were needed to achieve the optimum result of the highest extract concentration.

\section{Design-Expert ${ }^{\circ}$ Software \\ Trial Version \\ Factor Coding: Actual}

\section{concentration $(\mathrm{g} / \mathrm{I})$ \\ - Design points above predicted value \\ Design points below predicted value}

15.945

38.245

$\mathrm{X} 1$ = A: ratio of sample to solvent

X2 = B: particle size

\section{Actual Factor}

C: duration of extraction $=1.00$

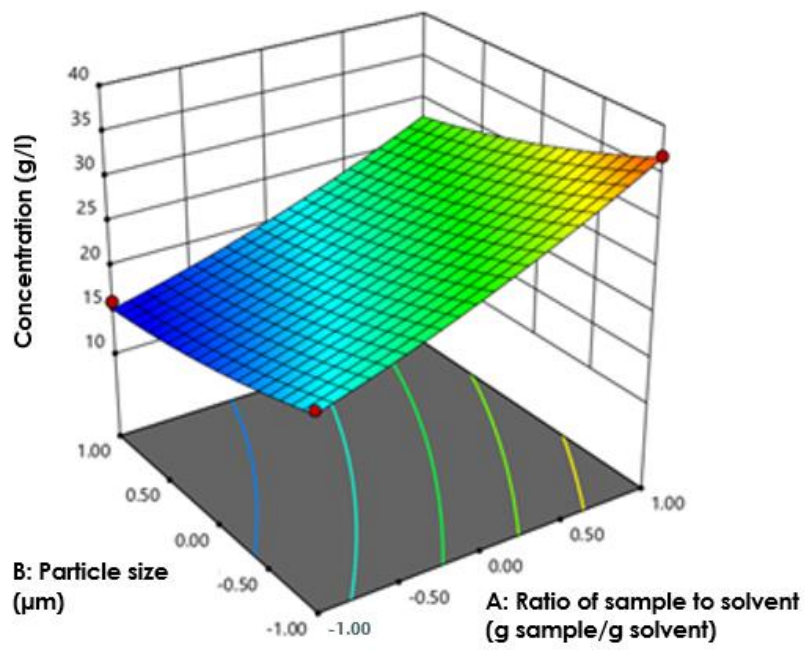

Figure 3 Response surface plot for the effect of the ratio of sample to solvent and particle size on CSL extract concentration 
Figure 4 demonstrates the three-dimensional response surface plot for the relationship of ratio sample to solvent and duration of extraction. It was determined that the highest concentration (38.245 ppm) was achieved when both red dots fell on the maximum point. Thus, it can be stated that the longest duration of extraction and the highest ratio of sample to solvent were required in order to achieve optimum result.

Figure 5 shows the response surface plot for the relationship between particle size and duration of extraction. When the largest particle size with a maximum duration of extraction was applied, the concentration achieved was mediocre as shown by the green region on the graph. Thus, the highest concentration of the extract was achieved when the maximum duration of extraction and the smallest particle size were applied during the extraction process as indicated by the red dot. This is due to the smaller size particle tends to have large total surface area that offer a huge mass transfer rate between the plant matrix and the solvent [22].

\section{Design-Expert $\odot$ Software \\ Trial Version \\ Factor Coding: Actual \\ concentration $(g / 1)$ \\ - Design points above predicted value \\ Design points below predicted value \\ 15.945

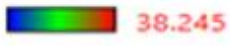

$X_{1}=A$ : ratio of sample to solvent

$\mathrm{X} 2$ = $\mathrm{C}$ : duration of extraction

\section{Actual Factor}

B: particle size $=-1.00$

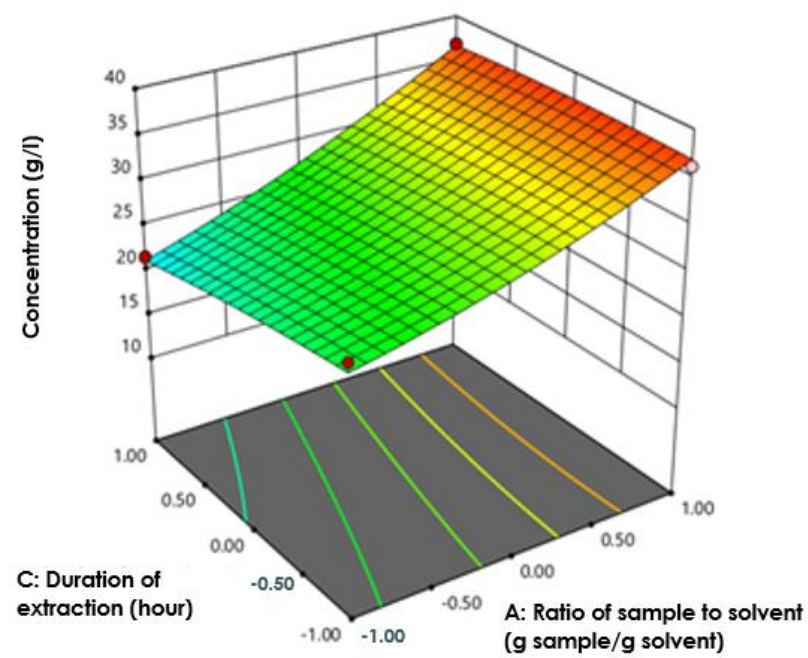

Figure 4 Response surface plot for the effect of ratio sample to solvent and duration of extraction on CSL extract concentration

\subsection{Validation of the Model}

Numerical optimization was selected to predict the maximum concentration from the combination of suggested parameters. The prediction of optimum conditions were determined from the Predicted Equation.

\section{Prediction Equation:}

Concentration $(\mathrm{ppm})=+24.34170+5.93343 *$ ratio of sample to solvent - $4.31573 *$ particle size -0.591444 * duration of extraction $-0.662750 *$ ratio of sample to solvent $*$ particle size $+1.11050 *$ ratio of sample to solvent $*$ duration of extraction $+0.630500 *$ particle size * duration of extraction $+1.00412 *$ ratio of sample to solvent ${ }^{2}+0.851561$ particle size ${ }^{2}-0.338499$

* duration of extraction ${ }^{2}$
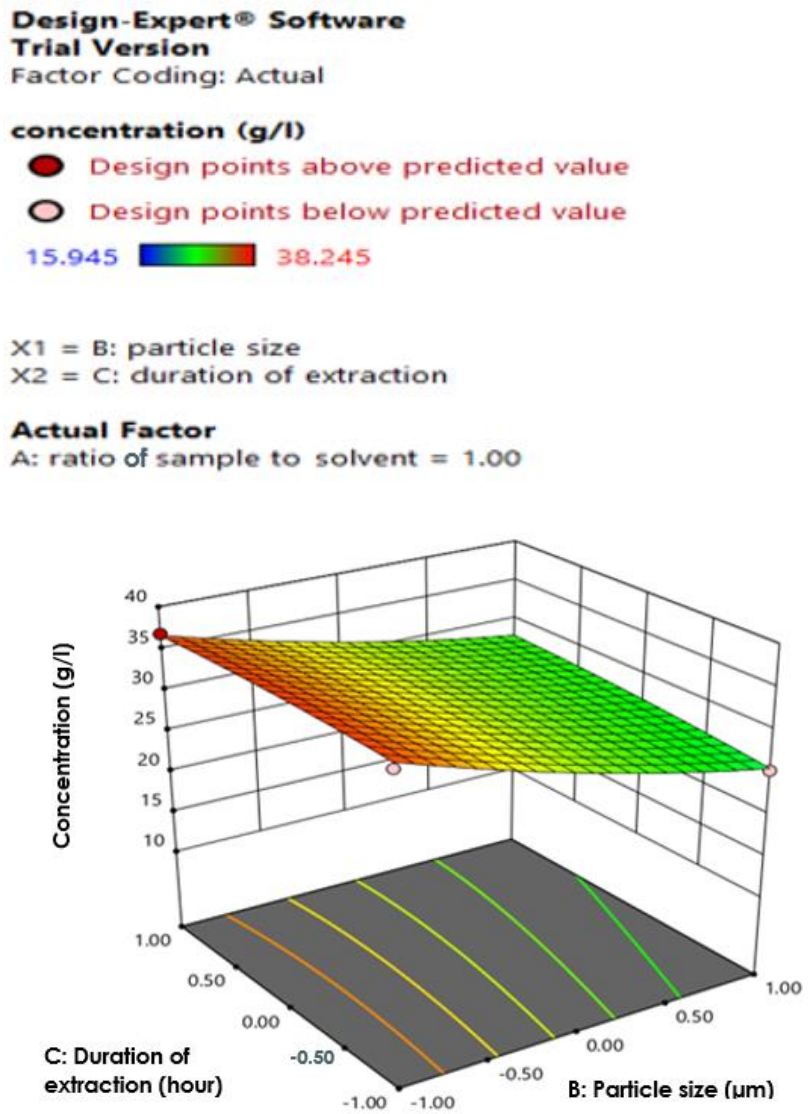

Figure 5 Response surface plot for the effect of particle size and duration of extraction on CSL extract concentration

The selected optimum conditions based on the equation is shown in Figure 6. Figure 6 shows the predicted value of ratio of sample to solvent, particle size, and duration of extraction from the optimization of reflux extraction condition using RSM. Based on Figure 6, the optimal conditions developed by the software for maximizing the conditions of the extract are at 2.5:20 ratio of sample to solvent, particle size of $0.125 \mu \mathrm{m}$ and 2.48 hours of extraction time. Under 
these optimal condition, the predicted condition is 37.1184 ppm.

To evaluate the accuracy of the optimum prediction, two replications of validation runs were done and the results were shown in Table 5. The mean error percentage difference was below $3 \%$ which proves the reliability of these results as shown in Table 3-4. The model proposed was accurate and satisfactory. The instability of the experimental error might be due to some noise during the reading of UV-vis spectrophotometer or maybe during the reflux extraction process.
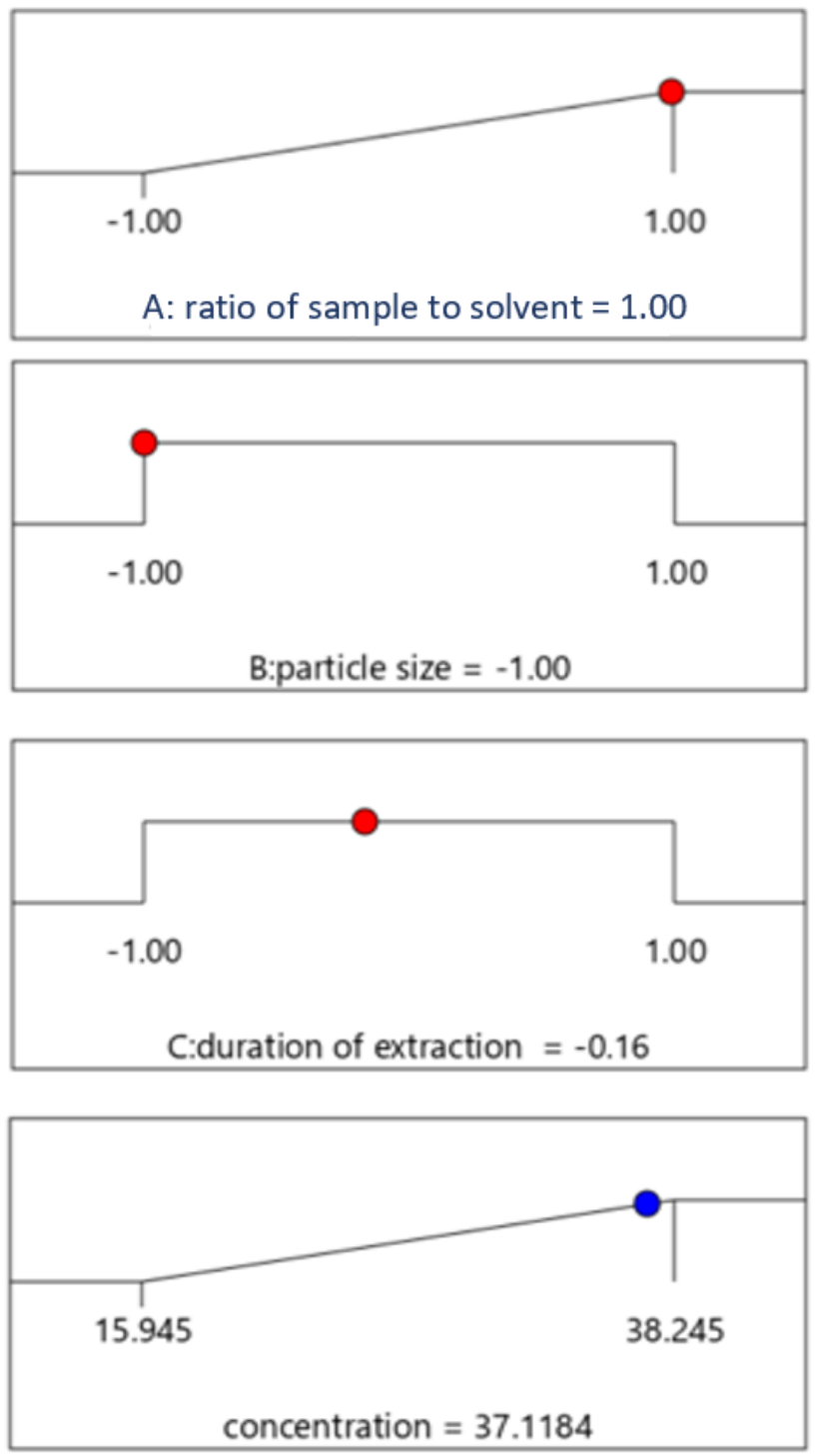

Figure 6 The ramping line (numerical) of the suggested optimum parameters and predicted optimum response (concentration)
Table 5 Verification study of the optimum conditions

\begin{tabular}{|c|c|c|c|c|c|c|}
\hline \multirow[t]{2}{*}{ Run } & \multirow{2}{*}{$\begin{array}{c}\text { A } \\
\text { (ratio of } \\
\text { sample } \\
\text { to } \\
\text { solvent) }\end{array}$} & \multirow{2}{*}{$\begin{array}{c}\text { B } \\
(\mathrm{mm})\end{array}$} & \multirow{2}{*}{$\begin{array}{l}\text { C } \\
\text { (hr) }\end{array}$} & \multicolumn{3}{|c|}{ Concentration } \\
\hline & & & & $\begin{array}{l}\text { Experimental } \\
(\mathrm{ppm})\end{array}$ & $\begin{array}{l}\text { Predicted } \\
\text { (ppm) }\end{array}$ & $\begin{array}{l}\text { Error } \\
\text { (\%) }\end{array}$ \\
\hline 1 & $2.5: 20$ & 0.125 & 2.48 & 35.893 & 37.1184 & 3.40 \\
\hline 2 & $2.5: 20$ & 0.125 & 2.48 & 36.382 & 37.1184 & 2.02 \\
\hline \multicolumn{3}{|c|}{ Mean error (\%) } & & & & 2.71 \\
\hline
\end{tabular}

\subsection{CONCLUSION}

The objective of this research is to optimize the reflux extraction of Caesalpinia sappan linn. (CSL) wood using Response Surface Methodology based on the different ratios of sample (CSL) to solvent (water), particle size, and duration of extraction. The application of Central Composite Design (CCD) method in RSM was used to evaluate the optimal conditions of concentration of CSL wood extract by using the DesignExpert software 11 . Different concentrations of extracts were evaluated based on different condition of the parameters. The predicted optimum condition was compared to experimental condition using the suggested optimum parameters. The optimum CSL extract concentration obtained from experiments were 35.893 ppm and $36.382 \mathrm{ppm}$, respectively. The percentage error of both optimize experimental conditions was less than $3 \%$. In conclusion, the best ratio of sample to solvent was 2.5:20, particle size of $0.125 \mathrm{~mm}$, and 2.48 hours for duration of extraction. The objectives of this research had been well performed and achieved.

\section{Acknowledgement}

The authors gratefully acknowledge the staffs of the Faculty of Chemical Engineering, Universiti Teknologi MARA Cawangan Pulau Pinang, Malaysia, for supporting this project.

\section{References}

[1] S. Badami, S. Moorkoth, and B. Suresh. 2004. Caesalpinia Sappan A Medical and Dye Yielding Plant. Nat. Prod. Radiance. 3(2): 75-82.

[2] N. P. Nirmal, M. S. Rajput, R. G. S. V. Prasad, and M. Ahmad. 2015. Brazilin from Caesalpinia Sappan Heartwood and Its Pharmacological Activities: A Review. Asian Pac. J. Trop. Med. 8(6): 421-430. Doi: 10.1016/j.apjtm.2015.05.014.

[3] D. K. Lee, D. H. Cho, J. H. Lee, and H. Y. Shin. 2008. Fabrication of Nontoxic Natural Dye from Sappan Wood. Korean J. Chem. Eng. 25(2): 354-358. Doi: 10.1007/s11814008-0058-6.

[4] M. Shahril. 2006. Optimization of Hydro Distillation Conditions for the Production of Essential Oil from Alpinia 
Galanga. University College of Engineering \& Technology Malaysia.

[5] B. Kaufmann and P. Christen. 2002. Recent Extraction Techniques for Natural Products: Microwave-assisted Extraction and Pressurised Solvent Extraction. Phytochem. Anal. 13(2): 105-113. Doi: 10.1002/pca.631.

[6] A. Nn. 2015. A Review on the Extraction Methods Use in Medicinal Plants, Principle, Strength and Limitation. Med. Aromat. Plants. 04(03): 3-8. Doi: 10.4172/21670412.1000196

[7] B. S. Larsen, M. A. Kaiser, M. Botelho, G. R. Wooler, and L. W. Buxton. 2005. Comparison of Pressurized Solvent and Reflux Extraction Methods for the Determination of Perfluorooctanoic Acid in Polytetrafluoroethylene Polymers using LC-MS-MS. Analyst. 130(1): 59-62. Doi: 10.1039/b412609b.

[8] M. Ariff and N. Abdullah. 2019. Optimization of Reflux Extraction for Cat's Whiskers Leaves Extract Using Response Surface Methodology. Chem. Ind. Chem. Eng. Q. 24-24. Doi: 10.2298/ciceq190228024a.

[9] L. S. Chua, N. A. Latiff, and M. Mohamad. 2016. Reflux Extraction and Cleanup Process by Column Chromatography for High Yield of Andrographolide Enriched Extract. J. Appl. Res. Med. Aromat. Plants. 3(2): 64-70. Doi: 10.1016/j.jarmap.2016.01.004.

[10] P. Arulpriya and P. Lalitha. 2013. Evaluation of Different Extraction Methods for Optimization of Extraction of Aerial Roots of Rhaphidophora Aurea Entwined Over Two Diverse Host Trees. Int. J. ChemTech Res. 5(5): 2173-2176.

[11] A. Hijazi, D. S. Al Masri, H. Farhan, M. Nasser, and H. Annan. 2015. Effect of Different Ethanol Concentrations, Using Different Extraction Techniques, on the Antioxidant Capacity of Lebanese Eryngium Creticum. J. Pharm. Chem. Biol. Sci. 3(August): 262-271. Doi: 10.1016/j.ijheatmasstransfer.2010.07.048.

[12] S. Christudas, T. M. Kulathivel, and P. Agastian. 2012. Phytochemical and Antibacterial Studies of Leaves of Tridax Procumbens L. Asian Pac. J. Trop. Biomed. 2(1 SUPPL.): S159-S161. Doi: 10.1016/S2221-1691(12)60149-X.

[13] R. Tabaraki and A. Nateghi. 2011. Optimization of Ultrasonic-Assisted Extraction Of Natural Antioxidants From Rice Bran Using Response Surface Methodology. Ultrason.
Sonochem.

18(6):

$1279-1286$

Doi:

10.1016/j.ultsonch.2011.05.004.

[14] T. Rakić, I. Kasagić-Vujanović, M. Jovanović, B. JančićStojanović, and D. Ivanović. 2014. Comparison of Full Factorial Design, Central Composite Design, and BoxBehnken Design in Chromatographic Method Development for the Determination of Fluconazole and Its Impurities. Anal. Lett. 47(8): 1334-1347. Doi: 10.1080/00032719.2013.867503.

[15] B. K. M. Demirel. 2012. Application of Response Surface Methodology and Central Composite Design for the Optimization of Textile Dye Degradation by Wet Air Oxidation. Demirel Kayan Int. J. Ind. Chem. 3(24): 1-10.

[16] Z. Chen et al. 2013. UV-vis Spectroscopy. Photocelectrochemical Water Splitting. 126.

[17] A. Cioabla. 2013. UV-vis Spectrophotometry: Principle and Applications. September.

[18] A. Ghasemzadeh and H. Z. E. Jaafar. 2014. Optimization of Reflux Conditions for Total Flavonoid and Total Phenolic Extraction and Enhanced Antioxidant Capacity in Pandan (Pandanus amaryllifolius Roxb.) Using Response Surface Methodology. Sci. World J. Doi: 10.1155/2014/523120.

[19] R. K. Salar, S. S. Purewal, and M. S. Bhatti. 2016. Optimization of Extraction Conditions and Enhancement of Phenolic Content and Antioxidant Activity of Pearl Millet Fermented with Aspergillus Awamori MTCC-548. Resour. Technol. 2(3): 148-157. Doi: 10.1016/j.reffit.2016.08.002.

[20] I. Soraya et al. 2017. Effects of Temperature, Time, and Solvent Ratio on the Extraction of Phenolic Compounds and the Anti - Radical Activity of Clinacanthus Nutans Lindau Leaves by Response Surface Methodology. Chem. Cent. J. 1-11. Doi: 10.1186/s13065-017-0285-1.

[21] S. Wang et al. 2014. Optimisation of the Ethanol-based Heat Reflux Extraction of Isoflavones from Pueraria Lobata (Willd.) Ohwi Root. 959: 180-186. Doi: 10.4028/www.scientific.net/AMR.955-959.180.

[22] S. A. Makanjuola. 2017. Influence of Particle Size and Extraction Solvent on Antioxidant Properties of Extracts of Tea, Ginger, and Tea-Ginger Blend. May: 1-7. Doi: 10.1002/fsn3.509. 